\title{
Effects of Divorce Risk on Women's Labor Supply and Human Capital Investment
}

\author{
Kristin Mammen \\ Department of Economics, School of Business College of Staten Island, City University of New York, New York, \\ USA \\ Email: Kristin.Mammen@csi.cuny.edu
}

Received 30 June 2015; accepted 23 August 2015; published 26 August 2015

Copyright (C 2015 by author and Scientific Research Publishing Inc.

This work is licensed under the Creative Commons Attribution International License (CC BY).

http://creativecommons.org/licenses/by/4.0/

\begin{abstract}
This paper examines the effects of the divorce law liberalization of the early $1970 \mathrm{~s}$ on the increase in divorce rates during the same time period. A review of the evidence suggests that the law changes were not a major driver of the divorce rates; but the policy changes appear to have affected behavior even for those who did not divorce. The results here suggest that as they saw the laws changing, young women in the divorce reform states redirected some of their investments from marriage to their own human capital. The perceived increase in the probability of divorce motivated women to improve their options outside of marriage.
\end{abstract}

\section{Keywords}

\section{Divorce Law Liberalization, Divorce Rate, Family Structure, Labor Supply, Marital Dissolution}

\section{Introduction}

Marriage has been a bedrock of American life; but in the past 50 years divorce has come to rival it as a social institution that will shape many families. Today the marriage rate in the U.S. is 6.8 marriages per 1000 population (U.S. Bureau of the Census, 2011), a historical low, and the divorce rate is 16.4 divorces per 1000 married women (Wilcox \& Marquardt, 2011).

Despite the decline in the marriage rate, Americans still highly value marriage. Marriage is a more prevalent and powerful social norm in the U.S. compared with many Western European countries (Cherlin, 2005). Second (and higher order) marriages after divorce are common (Furstenberg, 1994). The attachment to marriage is exemplified by the nationwide battle to obtain legal standing and public support for same-sex couples to marry, which very recently culminated in a Supreme Court decision stating that marriage is a constitutional right regardless of gender categories (Liptak, 2015). Nevertheless, on average, Americans are marrying later and spending less of their lifetimes married (Furstenberg, 1994), and as is well known about half of all marriages are 
expected to end in divorce (Castro Martin \& Bumpass, 1989).

The effect of the attenuation of marriage and the proliferation of divorce on individuals and on society as a whole has been widely debated in public discussion of American life. ${ }^{1}$ Psychologists and other social scientists agree broadly that divorce is most often painful and traumatic for the families involved (cf. Amato, 2010; Wallerstein \& Kelly, 1992). Both quantitative and qualitative evidence shows that the economic circumstances of families decline at the time of divorce, particularly for women and children (e.g., Kurz, 1995: Chapters 4 \& 5; Page \& Stevens, 2004). Divorced adults tend to have more physical and mental health ailments and lower life expectancies on average relative to married adults (Waite, 1995). On the other hand, many scholars argue that most adults recover emotionally from divorce in time and that some blossom in their new life circumstances (Hetherington, 2002).

Researchers differ also on the depth, breadth and duration of the harm suffered by children who have experienced their parents' divorce (e.g., Hetherington, 2002; Wallerstein \& Kelly, 1992). Children of divorced parents are more likely to drop out of school and have trouble finding a job, and daughters of these families are more likely to give birth as a teenager relative to children of parents who stay married (e.g., McLanahan \& Sandefur, 1994). Qualitative evidence documents the sadness of many children surrounding the divorce event which sometimes continues into adulthood (Marquardt, 2005; Wallerstein \& Kelly, 1992). It is generally agreed that children benefit when a very high-conflict or abusive marriage ends. But controversy surrounds the question of just how bad a marriage has to be for a divorce to be better for the child relative to continuing the marriage (Parke, 2003; Wilcox, 2009). Advocates of the traditional marriage ideal argue that the benefit of ending a marriage that is only "unsatisfactory" to a spouse is outweighed by damage to the children. Scholars and policymakers with the opposing view emphasize that most children of divorced parents grow up without serious problems (Parke, 2003).

Some social critics including psychologists have gone beyond studying individual families to attributing to the rise in divorce, the initiation of an unrelenting decline of the American family (e.g., Popenoe, 1993; Wilcox, 2009). A striking aspect of this argument is that fifty years later, the change to a no-fault divorce regime in the U.S., circa 1965, is still blamed as the fulcrum that increased divorce rates and began the erosion of the family which they hold continues to the present day (Vitz, 1998; Wilcox, 2009).

In this paper I briefly review the theoretical and empirical evidence on whether divorce law liberalization increased the divorce rate. This question has been studied from many different points of view and fields of expertise. Taken together, the evidence indicates that the divorce law changes had a fleeting effect, if any, on divorce rates. I then address how the Divorce Revolution might have affected the family via a different channel: prompting an increase in women's labor supply. I find evidence that the perception of an increased probability of divorce most likely reallocated some of women's investments in their marriages to investments in their own human capital. Women's ability to support themselves and their children has soared since 1965 . Women's increased labor supply unquestionably has affected the framework of the family; but I would argue that the increase in women's autonomy has been an overall gain that has strengthened many families regardless of their composition.

Figure 1 illustrates the dramatic increase in the American divorce rate which began around 1965 and did not level off until 1981. The rate has declined slowly since then but has not returned to 1950s levels. ${ }^{2}$ The steepest rise was between 1965 and 1975, when the divorce rate doubled from 10.6 to 20.3 divorces per 1000 married women. This upsurge largely coincided with the broad divorce reform of this time period: the liberalization of divorce laws in a large number of states to a unilateral regime, which made divorce easier by requiring the consent of only one spouse to dissolve a marriage (e.g., Friedberg, 1998; Weitzman, 1985). Table 1 shows the year of the switch to a unilateral law for each reform state; the vast majority changed their laws between 1965 and $1975 .{ }^{3}$

This divorce law liberalization was termed the "Divorce Revolution" by sociologist Lenore Weitzman (1985). The phrase has come to describe also the precipitous rise in the divorce rate, and a wider social phenomenon, the onset of a "divorce culture" replacing the older "marriage culture" (Council on Families in America, 1995; Whitehead, 1997). It is this Divorce Revolution that many social critics believe instigated a general decline in

1e.g. Coontz, 2013; Council on Families in America, 1995; Hochschild, 2002; Whitehead, 1997.

${ }^{2}$ The divorce rate began a slow rise from near-zero levels around the time of the Civil War. In the early $20^{\text {th }}$ century the rate surged after both of the World Wars, and plummeted during the Depression (Cherlin, 1992: p. 21). But the 1950s levels are in line with the gently rising trend line from the 1860s (Cherlin, 1992: Figure 1-5).

${ }^{3}$ The "no-change" states listed in Table 1 eventually liberalized their divorce laws long after 1981 when the divorce rate began to fall. 


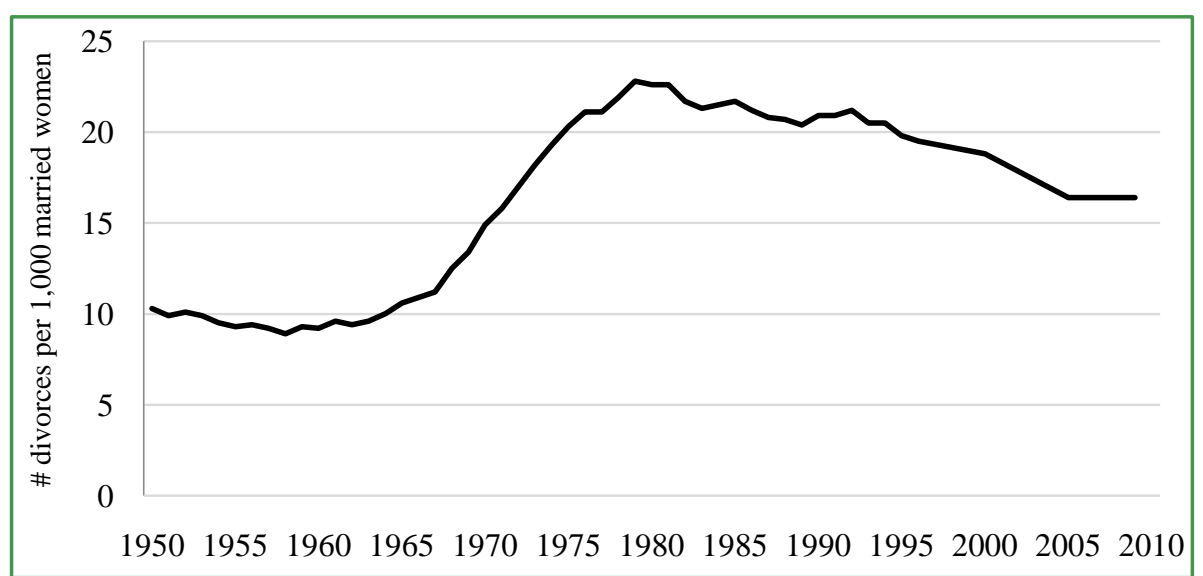

Figure 1. Divorce rate. Source: Clarke, 1995; U.S. Bureau of the Census 2001; Wilcox \& Marquardt, 2011.

Table 1. States’ changes to unilateral divorce.

\begin{tabular}{ccccc}
\hline States Which Never Changed & & State and Year Changed to Unilateral Divorce & Year \\
\hline State & State & Year & State & 1972 \\
\hline Arkansas & New Mexico & 1933 & Kentucky & 1972 \\
District of Columbia & Alaska & 1935 & Michigan & 1972 \\
Illinois & Oklahoma & 1953 & Nebraska & 1973 \\
Louisiana & Nevada & 1967 & Arizona & 1973 \\
Maryland & Delaware & 1968 & Connecticut & 1973 \\
Mississippi & Kansas & 1969 & Georgia & 1973 \\
Missouri & California & 1970 & Indiana & 1973 \\
New Jersey & Iowa & 1970 & Maine & 1973 \\
New York & Texas & 1970 & Montana & 1973 \\
North Carolina & Alabama & 1971 & Washington & 1974 \\
Ohio & Florida & 1971 & Minnesota & 1975 \\
Pennsylvania & Idaho & 1971 & Massachusetts & 1975 \\
South Carolina & New Hampshire & 1971 & Rhode Island & 1977 \\
Tennessee & North Dakota & 1971 & Wyoming & 1978 \\
Vermont & Oregon & 1971 & Wisconsin & 1985 \\
Virginia & Colorado & 1972 & South Dakota & 1987 \\
West Virginia & Hawaii & 1972 & Utah & \\
\hline
\end{tabular}

Notes: Adapted from Gruber (2004) Table 1.

the American family (e.g., Kirkwood, 1996; Parkman, 1993), and to which they point when advocating making divorce more difficult—-that is, returning to a 50-year-old legal system.

\section{The Effects of Divorce Law Liberalization}

The zero-order question in assessing the impact of the Divorce Revolution (by which I mean solely the change in the laws) is whether it had a causal effect on the divorce rate increase. Although it is prima facie intuitive that making divorce easier increased the incidence of divorce, the causality question has generated much discussion among researchers in economics, sociology, and the law. ${ }^{4}$ Two types of law changes constituted divorce law 
reform. The change from "fault" to "no-fault" substituted "irreconcilable differences" as a legal basis for divorce in place of grounds such as adultery or cruelty, which previously required formal proof and often resulted in perjury and collusion between spouses in order to obtain a legal divorce (Riley, 1991; Weitzman, 1985). The second, often overlapping, change was from the requirement that both spouses agree to divorce (mutual-consent) to only one (unilateral). Legal scholars have argued that the law changes were carried out "with little visibility or prominence" (Jacob, 1988: p. 15), by lawmakers and legal experts who wished to remove the unnecessarily adversarial elements from the proceedings and who felt the dignity of the law suffered from the machinations of judges, lawyers, and spouses to prove the often fabricated grounds (e.g., Freed \& Foster, 1979; Riley, 1991; Sepler, 1981). A number of scholars have therefore argued that the law changes were exogenous to the lives of those affected (e.g., Friedberg, 1998; Gruber, 2004; Wolfers, 2006).

Economists have focused on the transition from mutual-consent to unilateral laws in assessing causation between divorce law reform and divorce rates, because of the intriguing implications of the Coase theorem for this relationship (Coase, 1960; Becker, Landes, \& Michael, 1977). Assuming spouses can bargain costlessly, only efficient divorces will occur, those for which the total value of the marriage is less than the sum of the spouses' opportunities outside of marriage. The change to a unilateral divorce law changes assigned "property rights"-that is, who possesses the decision-making power over whether to divorce or not divorce. If spouses can easily bargain, who owns the property right will not change the incidence of divorce but can change the compensation schemes spouses devise which ensure these efficient outcomes. Within marriage, these schemes govern how spouses divide their time between market work, home production, and leisure. In the case of divorce, ownership of the property right dictates who will pay and who will profit from the divorce. Peters (1986) considered this model in depth and found that the divorce law regime was unrelated to divorce rates, but that the unilateral regime was associated with lower settlements for women, a result consistent with the idea that husbands who wished to leave marriages could decrease compensation to their wives under unilateral regimes relative to mutual consent. Weitzman (1985) provided anecdotal evidence that longtime housewives suffered from the switch to the unilateral regime because they had little leverage to claim part of the marital property.

Peters and other scholars have explored theoretical conditions under which the Coase theorem would not apply and divorce law reform would change divorce rates (Chiappori, Iyigun, \& Weiss, 2007; Mechoulan, 2005, 2006; Rasul, 2006). Debate continues on the empirical side as well. Allen (1992) disputed Peters' results, finding that the divorce law change did increase divorce rates. Friedberg (1998) using longitudinal data found strong effects of divorce law reform, but Wolfers (2006) argues that the effect was transitory.

Regarding the zero-order question, the evidence suggests any direct increase in the divorce rate from the divorce law changes was small. So it appears turning back the clock to make divorce more difficult would do little to push the American family back into its traditional box (cf. Furstenberg, 1994).

But even if a particular individual did not divorce as a result of the divorce law reform, an increase in the perceived risk of divorce potentially changed her behavior even if the effect on divorce rates was not long term. A reduction in expected marriage duration reduces the value of specialization and marriage-specific investments. This may be particularly important for women because their human capital acquisition is traditionally more focused on marriage-specific home production skills whose value may be dissipated when a marriage dissolves, whereas the value of market skills, held by men in greater proportion, may be more transferable to the single state. The reassignment of the right to divorce also shifts bargaining power from the spouse who most values the marriage to the spouse most interested in divorce. Divorce law reform may then precipitate behavioral changes, with "weaker" spouses accommodating the stronger spouse's preferences or attempting to maintain bargaining power by improving their outside options-through increasing market work, for example. Attachment to marriage will vary over individuals, but it is likely that the spouse with fewer options is often the wife, since women's economic circumstances decline on average after divorce (e.g., Duncan \& Hoffmann, 1985) and they are likely to bear more of the subsequent childrearing costs (Weitzman, 1985).

Female labor force participation is rising at the same time as the divorce rate, but Figure 2 shows that the divorce rate does not track with the long steady rise of labor force participation (which began about 1900 (Goldin, 2000)).

The response of women's labor supply to divorce risk and to changes in divorce law has already received attention in the literature. Johnson and Skinner (1986) find that married women increase their labor supply prior to a divorce, and argue that the increase results from the anticipation of divorce, rather than precipitating the divorce. Cross-sectional results often show a positive association between divorce law reform and women's labor 


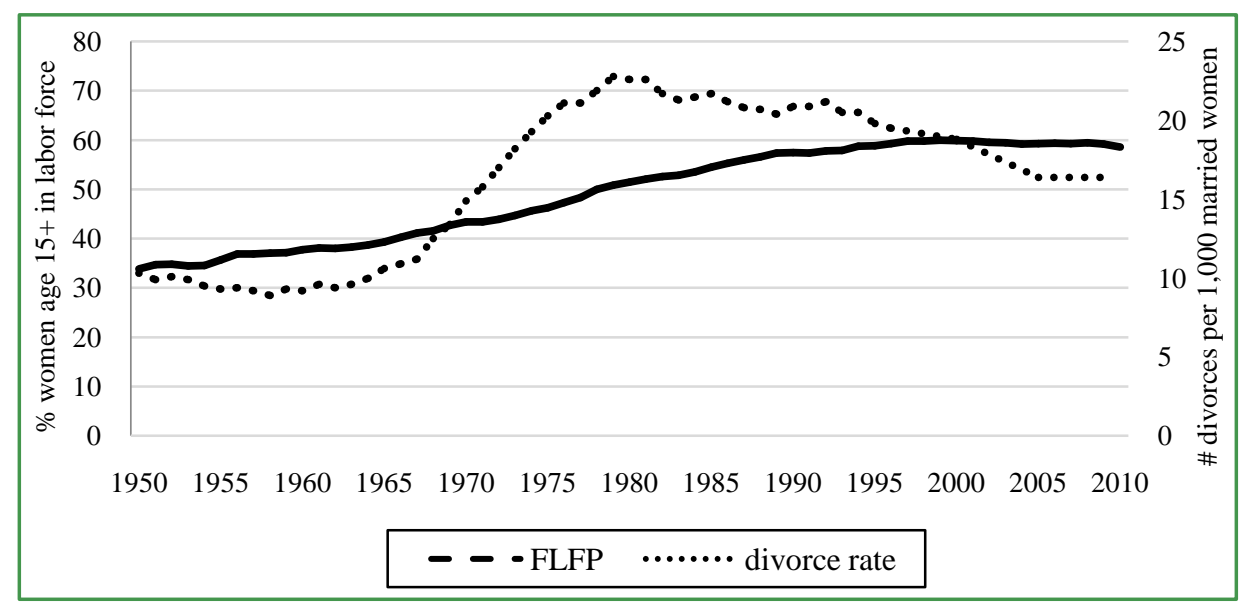

Figure 2. Divorce rates and female labor force participation. Sources: Clarke, 1995; U.S. Bureau of Labor Statistics, 2014; U.S. Bureau of the Census, 1975; Wilcox \& Marquardt, 2011.

supply, while longitudinal results are more mixed. ${ }^{5}$ Genadek, Stock and Stoddard (2007) argue that differing results could be explained by heterogeneous impacts of divorce law changes, if women have different costs of bargaining and divorce. They find that divorce law reform increases the labor supply of married mothers, especially those with young children, relative to other women for whom divorce is likely to be less costly.

The probability of divorce decreases with a person's age and with the duration of a marriage (e.g., Clarke, 1995), so the shock of a divorce law change may have had different effects on couples in more or less stable periods in the marriage cycle. In addition, the impact of a law change could depend in other ways on the life stage of the individual when the law change occurs: young women may have greater scope than older women to change their education paths, career investments, and other life choices when they see the terms of the marriage contract changing around them. So it is useful to look at women by age cohort as in Figure 3.

I use the March Current Population Survey (CPS) data from 1963 to 1999 to compare graphically the labor force participation (LFP) of women aged 15 - 62 in states which liberalized their laws and in those which never changed their laws. The CPS is a large, nationally representative household survey with comparable information for women in each year over this time period. ${ }^{6}$ The data are a repeated series of cross-sections so individuals cannot be tracked longitudinally. However, "synthetic cohorts" can be tracked over long periods of time (e.g., Lleras-Muney, 2005). We form a synthetic cohort by linking women of age $a$ in survey wave $t$ to women of age $a+1$ in wave $t+1$, and so on. Then the average characteristics of this cohort over time are representative of the characteristics of an individual woman followed over the same time period. In Figure 3, cohort profiles are plotted by grouping women observed in each calendar year by their birth years (here in 10-year spans), calculating their average participation rate in that year, and linking these rates from year to year. Following cohorts allows disentangling life-cycle (or age) effects from generational (or cohort) differences. Each profile-pairing of a solid and a dashed line represents the experience of a cohort as it ages, where the age denoted on the $\mathrm{x}$-axis is the midpoint of the age range for the cohort in any given survey year. The oldest cohort shown was born between 1915 and 1924, the profile on the lower right, and the youngest was born between 1955 and 1964, on the upper left.

Most striking in the figure is the across-cohort increase in women's LFP-each profile is higher at any given age as we look from the lower right to the upper left, that is, from older to younger cohorts. The second notable difference, within cohorts, is in the effects of living in states which changed their laws, represented by the solid line for each cohort, versus in no-change states, represented by the dashed line. First consider the middle profile, for the cohort born 1935-44. Since we first observe these women in 1963 (at ages 19 - 28), the first twelve years of their profile covers the most active period of divorce law liberalization, through 1975. At the beginning of

\footnotetext{
${ }^{5}$ Chiappori, Fortin, \& Lacroix, 2002; Parkman, 1993; Peters, 1986, 1992; Gray, 1986; Stevenson, 2008.

${ }^{6}$ For the periods 1968-72 and 1973-76, some states were not individually coded in the CPS, but were put into regional groupings which differed between these two time periods. States that are in homogenous groups (all law-changing states or all no-change states) are included in the data, but states in heterogeneous groupings in a time period are excluded for those years.
} 


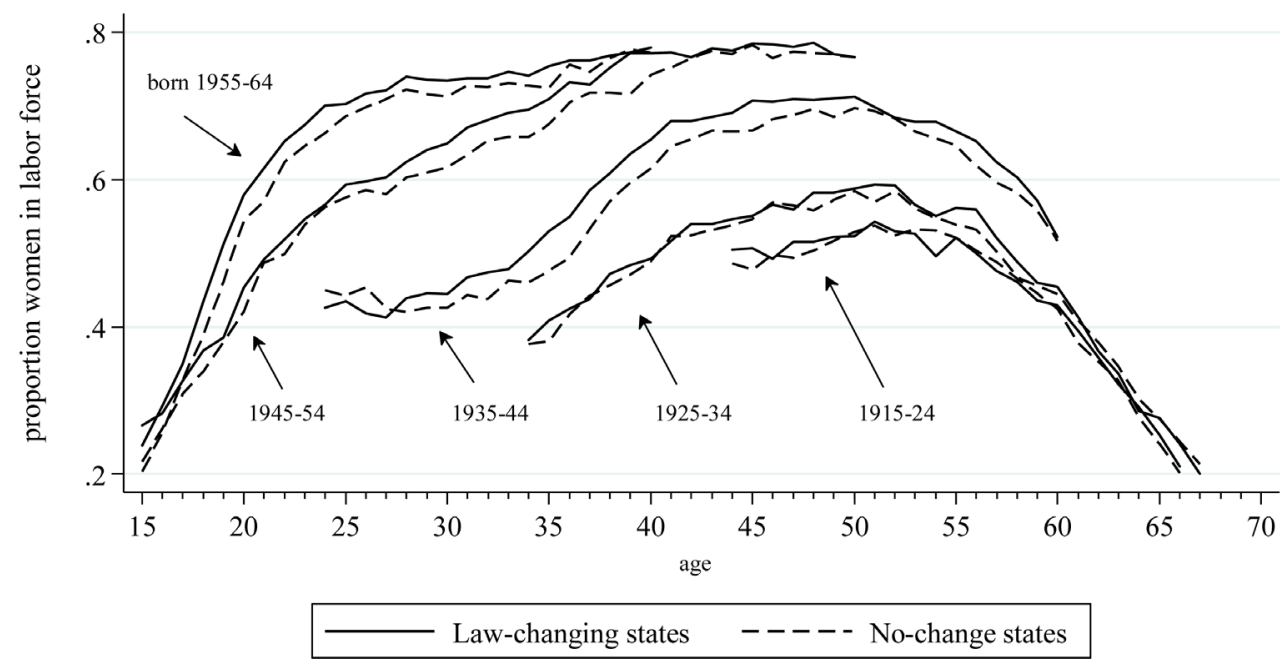

Figure 3. Women's labor force participation by ten-year age cohorts. Author's calculations, March CPS 1963-1999, women age 15 - 62.

this period, the LFP rate in the "never" states is greater, but the rate in the law-changing states overtakes it and is statistically significantly greater for ages 31 - 47. This is suggestive that the law changes were associated with increased LFP by women, as they saw the likelihood of divorce spike for their cohort with the law changes. Contrast this with the older cohorts, born 1915-24 and 1925-34: again the first twelve years of the profile covers the liberalization period, but for these two cohorts there is no notable difference between the two lines. It seems likely that the law changes had little effect on LFP for these older cohorts for two reasons: with longer-lived and more stable marriages, the change in the risk of divorce was not as great, and their work options were likely more limited than those of younger women. For the 1945-54 cohort, the second youngest in the figure, the first twelve years of the profile show little difference for women in the two types of states. Around age 25, however, LFP for women in the law-changing states surpasses that of women in no-change states, and this difference is statistically significant for ages $27-42$. This is consistent with women in the law-changing states choosing to work during their child-bearing ages (cf. Genadek, Stock, \& Stoddard, 2007). The youngest cohort, born 1955-64, comes of working age after the law changes are complete. The LFP for women in the law-changing states is higher for most of the years we observe them, significantly so for ages 15 - 31, suggesting that higher women's LFP has become a norm in these states.

The evidence is suggestive that the law changes had an important effect on the labor supply decisions of women who reached their mid-twenties during the divorce law liberalization and shortly thereafter. The effect appears to persist, although at a lower level, for the youngest cohort of women, for whom the law changes were in place by their midteens.

\section{Conclusion}

The evidence in this study supports the argument that the divorce law changes had powerful unforeseen effects (Jacob, 1988; Parkman, 1993) and that the major effects resulted not from the fleetingly increased divorce rates but through behavioral changes of those who did not divorce (Gruber, 2004). The evidence is consistent with the notion that within families trade-offs were made between marriage-specific investments and individual's investments that would be more valuable if the marriage ended (i.e., women's increasing labor supply). Divorce law reform changed the terms of marriage contracts that couples were contemporaneously engaged in without consideration of the long term effects on incentives to make these investments.

Marital status continues to be an important predictor of well-being (Waite, 1995) and the health of the American family is well deserving of attention. However, the argument that divorce law liberalization was a major driver of increasing divorce rates is weak; and correspondingly the notion of making divorces more difficult to obtain seems unlikely to reverse the plethora of changes in the American family that have occurred over the past fifty years.

The difficult ramifications of divorce are easier to quantify than the benefits. But women’s increased labor 
force participation has clearly put them on a more equal footing with men both within and outside marriage. I would argue that doing more to support the American family in its current forms is likely to be more productive than seeking to return to narrow and outdated ideals of family structure.

\section{References}

Allen, D. (1992). Marriage and Divorce: Comment. American Economic Review, 82, 679-685.

Amato, P. (2010). Research on Divorce: Continuing Trends and New Developments. Journal of Marriage and Family, 72 , 650-666. http://dx.doi.org/10.1111/j.1741-3737.2010.00723.x

Becker, G, Landes. E., \& Michael, R. T. (1977). An Economic Analysis of Marital Instability. Journal of Political Economy, 85, 1141-1187. http://dx.doi.org/10.1086/260631

Brinig, M. F., \& Buckley, F. H. (1998). No-Fault Laws and At-Fault People. International Review of Law and Economics, 18, 325-340. http://dx.doi.org/10.1016/S0144-8188(98)00008-8

Castro Martin, T., \& Bumpass, L. (1989). Recent Trends and Differentials in Marital Disruption. Demography, $26,37-51$. http://dx.doi.org/10.2307/2061492

Cherlin, A. (1992). Marriage, Divorce, Remarriage. Cambridge: Harvard University Press.

Cherlin, A. (2005). American Marriage in the Early Twenty-First Century. The Future of Children, 15, 33-55. https://www.princeton.edu/futureofchildren/publications/journals/article/index.xml?journalid=37\&articleid=105\&sectioni $\mathrm{d}=674$ http://dx.doi.org/10.1353/foc.2005.0015

Chiappori, P., Fortin, B., \& Lacroix, G. (2002). Marriage Market, Divorce Legislation and Household Labor Supply. Journal of Political Economy, 10, 37-72. http://dx.doi.org/10.1086/324385

Chiappori, P., Iyigun, M., \& Weiss, Y. (2007). Public Goods, Transferable Utility and Divorce Laws. IZA Discussion Paper No. 2346. http://www.iza.org/en/webcontent/publications/papers/viewAbstract?dp_id=2646

Clarke, S. C. (1995). Advance Report of Final Divorce Statistics, 1989 and 1990. Monthly Vital Statistics Report, 43. Hyattsville, Maryland: National Center for Health Statistics. http://www.cdc.gov/nchs/data/mvsr/supp/mv43_09s.pdf

Coase, R. (1960). The Problem of Social Cost. Journal of Law and Economics, 3, 1-44. http://dx.doi.org/10.1086/466560

Coontz, S. (22 June 2013). The Disestablishment of Marriage. New York Times.

http://www.nytimes.com/2013/06/23/opinion/sunday/coontz-the-disestablishment-of-marriage.html

Council on Families in America (1995). Marriage in America: A Report to the Nation. New York: Institute for American Values. http://www.americanvalues.org/search/item.php?id=24

Duncan, G., \& Hoffmann, S. (1985). A Reconsideration of the Economic Consequences of Marital Dissolution. Demography, 22, 485-497. http://dx.doi.org/10.2307/2061584

Ellman, I. (2000). Divorce Rates, Marriage Rates, and the Problematic Persistence of Marital Roles. Family Law Quarterly, 34, 1-42. http://dx.doi.org/10.2139/ssrn.224700

Ellman, I., \& Lohr, S. (1998). Dissolving the Relationship between Divorce Laws and Divorce Rates. International Review of Law and Economics, 18, 341-359. http://dx.doi.org/10.1016/S0144-8188(98)00014-3

Freed, D., \& Foster, H. H. (1979). Divorce in the Fifty States: An Overview as of 1978. Family Law Quarterly, 13, $105-128$.

Friedberg, L. (1998). Did Unilateral Divorce Raise Divorce Rates? Evidence from Panel Data. American Economic Review, 88, 608-627.

Furstenberg, F. (1994). History and Current Status of Divorce in the United States. The Future of Children, 4, $29-43$. http://dx.doi.org/10.2307/1602476

Genadek, K., Stock, W., \& Stoddard, C. (2007). No-Fault Divorce Laws and the Labor Supply of Women with and without Children. Journal of Human Resources, 42, 247-274.

Glenn, N. (1997). A Reconsideration of the Effect of No-Fault Divorce on Divorce Rates. Journal of Marriage and the Family, 59, 1023-1025. http://dx.doi.org/10.2307/353800

Goldin, C. (2000). Labor Markets in the Twentieth Century. In S. L. Engerman, \& R. E. Gallman (Eds.), The Cambridge Economic History of the United States (pp. 549-624). Cambridge: Cambridge University Press.

Gray, J. (1996). The Economic Impact of Divorce Law Reform. Population Research and Policy Review, 15, 275-296. http://dx.doi.org/10.1007/BF00127053

Gruber, J. (2004). Is Making Divorce Easier Bad for Children? The Long Run Implications of Unilateral Divorce. Journal of Labor Economics, 22, 799-833. http://dx.doi.org/10.1086/423155 
Hetherington, E. M. (8 April 2002). Marriage and Divorce American Style: A Destructive Marriage Is Not a Happy Family. The American Prospect. http://prospect.org/article/marriage-and-divorce-american-style

Hochschild, A. (20 March 2002). Taking Care. The American Prospect. http://prospect.org/article/taking-care

Jacob, H. (1988). Silent Revolution: The Transformation of Divorce Law in the United States. Chicago, IL: University of Chicago Press.

Johnson, W., \& Skinner, J. (1986). Labor Supply and Marital Separation. American Economic Review, 76, 455-456.

Kirkwood, C. (June 17 1996). No-Fault Divorces under Increasing Attack. Insight on the News 12(23). https://www.questia.com/magazine/1G1-18375280/no-fault-divorces-under-increasing-attack

Kurz, D. (1995). For Richer For Poorer: Mothers Confront Divorce. London: Routledge.

Liptak, A. (27 June 2015). Supreme Court Ruling Makes Same-Sex Marriage a Right Nationwide. New York Times.

Lleras-Muney, A. (2005). The Relationship between Education and Adult Mortality in the United States. Review of Economic Studies, 72, 189-221.

Marquardt, E. (2005). Between Two Worlds: The Inner Lives of Children of Divorce. New York: Crown Publishers.

McLanahan, S., \& Sandefur, G. (1994). Growing Up With a Single Parent: What Hurts, What Helps. Cambridge, MA: Harvard University Press.

Mechoulan, S. (2005). Economic Theory's Stance on No-Fault Divorce. Review of the Economics of the Household, 3, 337359.

Mechoulan, S. (2006). Divorce Laws and the Structure of the American Family. Journal of Legal Studies, 35, 143-174. http://dx.doi.org/10.1086/498832

Nakonezny, P., Shull, R., \& Rodgers, J. L. (1995). The Effect of No-Fault Divorce Law on the Divorce Rate across the 50 States and Its Relation to Income, Education and Religiosity. Journal of Marriage and the Family, 57, 477-488. http://dx.doi.org/10.2307/353700

Page, M., \& Stevens, A. (2004). The Economic Consequences of Absent Parents. Journal of Human Resources, 39, 80-107. http://dx.doi.org/10.2307/3559006

Parke, M. (2003) Are Married Parents Really Better for Children? Couples and Marriage Series Brief No. 3. Washington, DC: Center for Law and Social Policy. http://www.clasp.org/resources-and-publications/states/0086.pdf

Parkman, A. (June 1993). Terms of Endearment. Reason, 25, 29-33.

Peters, H. E. (1986). Marriage and Divorce: Informational Constraints and Private Contracting. American Economic Review, $76,437-454$

Peters, H. E. (1992). Marriage and Divorce: Reply. American Economic Review, 82, 686-693.

Popenoe, D. (1993). American Family Decline, 1960-1990: A Review and Appraisal. Journal of Marriage and Family, 55, 527-542. http://dx.doi.org/10.2307/353333

Rasul, I. (2006). Marriage Markets and Divorce Laws. Journal of Law, Economics, and Organization, 22, 30-69. http://dx.doi.org/10.1093/jleo/ewj008

Riley, G. (1991). Divorce: An American Tradition. Oxford: Oxford University Press.

Rodgers, J. L., Nakonezny, P., \& Shull, R. (1999). Did No-Fault Divorce Legislation Matter? Definitely Yes and Sometimes No. Journal of Marriage and the Family, 61, 803-809. http://dx.doi.org/10.2307/353580

Sepler, H. (1981). Measuring the Effects of No-Fault Divorce Laws across Fifty States: Quantifying a Zeitgeist. Family Law Quarterly, 15, 65-102.

Stevenson, B. (December 2008). Divorce Law and Women’s Labor Supply. Journal of Empirical Legal Studies, 5, 853-873.

U.S. Bureau of Labor Statistics (2014) Current Population Survey Household Averages Table 2. http://www.bls.gov/cps/cpsa2014.pdf

U.S. Bureau of the Census (1975). Historical Statistics of the United States, Colonial Times to 1970. Bicentennial Edition, Part 1. Washington DC.

https://ia600407.us.archive.org/4/items/HistoricalStatisticsOfTheUnitedStatesColonialTimesTo1970/us_historical_statistic s_colonial_times_to_1970.pdf

U.S. Bureau of the Census (2001). Statistical Abstract of the United States: 2001. Washington, DC. https://www.census.gov/prod/2002pubs/01statab/vitstat.pdf

U.S. Bureau of the Census (2011). Statistical Abstract of the United States: 2012. Washington, DC. https://www.census.gov/compendia/statab/2012/tables/12s0133.pdf

Vitz, P. (1998). Family Decline: The Findings of Social Science. Part I in Defending the Family: A Sourcebook (pp. 1-23). Steubenville, OH: The Catholic Social Science Press. 
http://www.catholiceducation.org/en/controversy/marriage/family-decline-the-findings-of-social-science.html

Waite, L. (November 1995). Does Marriage Matter? Demography, 32, 483-507.

Wallerstein, J., \& Kelly, J. (1992). Surviving the Breakup: How Children and Parents Cope with Divorce. New York: Basic Books.

Weitzman, L. (1985). The Divorce Revolution: The Unexpected Social and Economic Consequences for Women and Children in America. New York: Free Press.

Whitehead, B. (1997). The Divorce Culture. New York: Knopf.

Wilcox, W. (2009). The Evolution of Divorce. National Affairs, 1, 81-94.

http://www.nationalaffairs.com/publications/detail/the-evolution-of-divorce

Wilcox, W., \& Marquardt, E. (2011). How Parenthood Makes Life Meaningful and How Marriage Makes Parenthood Bearable. Charlottesville, VA: National Marriage Project/Institute for American Values.

http://americanvalues.org/catalog/pdfs/state_of_our_unions_2011.pdf

Wolfers, J. (2006). Did Unilateral Divorce Raise Divorce Rates? A Reconciliation and New Results. American Economic Review, 96, 1802-1820. http://dx.doi.org/10.1257/aer.96.5.1802 